\title{
The Search for More pH Stable Stationary Phases for High Performance Liquid Chromatography
}

\author{
Carol H. Collins, * César R. Silva, Anizio M. Faria, ${ }^{\#}$ Kenneth E. Collins and Isabel Cristina S. F. Jardim \\ Instituto de Química, Universidade Estadual de Campinas, CP 6154, 13083-970 Campinas-SP, Brazil
}

\begin{abstract}
As separações por cromatografia líquida de alta eficiência (CLAE) são realizadas, na maioria das vezes, em condições de fase reversa empregando fases estacionárias a base de sílica. Um problema sério com estas fases reversas é a tendência da sílica dissolver em soluções de $\mathrm{pH}$ elevado, frequentemente necessárias para separar compostos básicos. A literatura reporta várias maneiras diferentes de tentar solucionar este problema. Este artigo relata os resultados obtidos com fases estacionárias desenvolvidas no nosso laboratório, utilizando suportes de sílica, contendo uma camada de um óxido metálico (zircônia ou titânia) ligada à sua superfície, seguido por imobilização de um polissiloxano ou por organofuncionalização com um trimetóxialquilsilano. Testes de estabilidade, também desenvolvidos no nosso laboratório, indicaram que a camada de óxido metálico aumenta o tempo de vida da coluna cromatográfica, por tornar a fase estacionária menos susceptível à dissolução.
\end{abstract}

High performance liquid chromatographic (HPLC) separations are largely carried out using reversed phase conditions with stationary phases based on silica. A serious problem with these stationary phases is the tendency of silica to dissolve in high $\mathrm{pH}$ solutions often needed to separate basic compounds. The literature reports many different ways that have been tried to resolve this problem. This paper reports the results obtained in our laboratory with stationary phases prepared using silica supports having a layer of a metal oxide (zirconia or titania) attached on their surfaces, followed by immobilization of a polysiloxane or by organofunctionalization with a trimethoxyalkylsilane. Stability tests, also developed in our laboratory, indicate that the metal oxide layer increases the HPLC column lifetimes by making the stationary phase less susceptible to dissolution.

Keywords: HPLC, stationary phases, reversed phases, metalized silica, immobilization, organofunctionalization

\section{Introduction}

High performance liquid chromatography (HPLC) has a very prominent place in the arsenal of tools available for analytical purposes. Within HPLC, the great majority of separations are carried out using the so-called "reversed phases", which use less polar stationary phases and polar, water-based mobile phases.

Pressurized liquid chromatography began in the mid1960 's. The earliest stationary phases were relatively large particles $(40-50 \mu \mathrm{m})$ of silica, for normal phase chromatography, and polymers (mainly polystyrenedivinylbenzene) or silica with coatings of a viscous liquid

*e-mail: chc@iqm.unicamp.br

\#Present address: Química-FACIP, Universidade Federal de Uberlândia, 38302-000 Ituiutaba - MG, Brazil phase, usually one of the many then available for gas chromatography, for reversed phase chromatography. With development of small $(5-10 \mu \mathrm{m})$ silica particles ${ }^{1}$ and subsequent need for higher pressures to force mobile phase through them, it became obvious that the liquid stationary phase needed to be fixed to a support. Early works on this, all using the omnipresent silanol groups of small silica particles, focused on three possible routes: $(i)$ esterification, producing $\mathrm{Si}-\mathrm{O}-\mathrm{C}$ bonding, by direct reaction of silanols with an alcohol; ${ }^{2}$ (ii) substitution of hydroxyl by a chloro using thionyl chloride, followed by reaction with an alcohol, also producing an ester, ${ }^{3}$ a Grignard reagent, producing a Si-C bond, ${ }^{4}$ or an amine, to give $\mathrm{Si}-\mathrm{N}-\mathrm{C},{ }^{5}$ and (iii) reaction with a chloro or alkoxysilane, to produce the Si-O-Si-C linkage. ${ }^{6,7}$ This latter reaction produces a stationary phase with the best hydrolytic stability in basic 
solutions and now dominates the preparation of commercial stationary phases. ${ }^{8}$

Once the fundamental chemistry for preparation of stationary phases on small silica particles had been established, the emphasis become that of developing phases that had better thermal and $\mathrm{pH}$ stabilities, as well as specialized phases for dedicated applications. Better thermal stability permits use of higher temperatures that reduce mobile phase viscosity, leading to a wider range of mobile phase components, as well as faster flow rates that reduce analysis time. A wider range of $\mathrm{pH}$ stability of both the stationary phase itself and of its support permits use of higher $\mathrm{pH}$ to suppress amine protonation and lower $\mathrm{pH}$ to suppress the ionization of acidic solutes. Without $\mathrm{pH}$ control both these processes may lead to irreversible retention of solutes on the stationary phase.

Most stationary phases are prepared from silica and monofunctional silanes, such as chlorodimethyloctadecylsilane, which produces an apolar stationary phase. The so-called polymeric phases are produced from trifunctional silanes such as octadecyltrichlorosilane. Both types of silane can also have functionality at the end of their long alkyl chain, opening up a wide variety of possible stationary phases for specialized separations. However, due to steric hindrance, these organofunctionalization reactions usually occur with less than half of the available silanols. Thus, the majority of these phases require an "endcapping" reaction with smaller reagents such as trimethylchlorosilane (TMCS) and/or hexamethyldisilazane (HMDS) to reduce the number of residual silanols. ${ }^{9}$ However, many silanols still remain on surface, becoming sites for basic dissolution of the silica support.

Use of trifunctional silanes in the presence of a wellcontrolled amount of water results in polymeric phases that show better stability at higher $\mathrm{pH} .{ }^{10}$ However, this reaction is less reproducible, compared with that which uses a monofunctional silane and still requires an endcapping reaction to reduce the presence of unreacted silanols. In addition, larger amounts of long alkyl chains on the surface may result in slower mass transfer kinetics so that the optimal mobile phase flow rates are lower and analysis times are longer.

Other approaches to reduce the presence and problems caused by the silanols use a monofunctional silane having bulkier groups instead of methyl on the silane, ${ }^{11}$ a bidentate silanization reagent having an ethylene ${ }^{12}$ or propylene ${ }^{13}$ bridge between two silicon atoms, or silanization reagents having polar groups such as amide, ${ }^{14,15}$ carbamate, ${ }^{16}$ urea ${ }^{17,18}$ or thiocarbamate ${ }^{19}$ built into the long alkyl chain. A further approach has been to prepare stationary phases using a mixture of reagents, such as octadecyltrichlorosilane and methyltrichlorosilane, resulting in the so-called horizontal polymerization..$^{20,21}$

Recently, the silica support has been modified by insertion of methyl $1^{22,23}$ or ethylene bridging ${ }^{24}$ groups into its structure by carrying out sol-gel process with a mixture of tetraethoxysilane and either methyltriethoxysilane or bis(triethoxysilyl)ethane. This reduces the number of silanols available on the support surface. These phases present efficiencies and pressure resistance similar to phases based on pure silica but have significantly better $\mathrm{pH}$ stabilities. However, as a result of having fewer silanols, the coverages with the long chain alkyl groups needed for reversed phase interactions of these hybrid phases are lower than the coverages of stationary phases based on pure silica.

Another way to enhance both thermal and $\mathrm{pH}$ stability is to substitute silica with another support material. Stationary phases based on cellulose or polymers such as polystyrenedivinylbenzene have been used but suffer from low resistances to the higher pressures presently being applied to increase flow rates and lower analysis times, ${ }^{25}$ although they still find considerable applications in ion exchange and size exclusion chromatographies. Graphitic carbon has also been promoted as useful over wide temperature and $\mathrm{pH}$ ranges ${ }^{26}$ but has limited possibilities for surface modification.

Porous inorganic materials, such as zirconia $\left(\mathrm{ZrO}_{2}\right)$, titania $\left(\mathrm{TiO}_{2}\right)$ and alumina $\left(\mathrm{Al}_{2} \mathrm{O}_{3}\right)$ should, in principal, have the same chromatographic properties as silica. ${ }^{27-30}$ However, these supports are also harder to organofunctionalize, due to the low number of available hydroxyl groups on their surfaces; resulting in lower coverage and thus requiring longer columns with more content to maintain appropriate resolutions. This problem has been reduced by depositing polymers, such as polybutadiene or polystyrene, on the oxide surfaces. Zirconia supports having these polymers on their surfaces have proved useful for separations up to $200{ }^{\circ} \mathrm{C}$ using water as mobile phase. ${ }^{31,32}$

Another route to more $\mathrm{pH}$ and temperature stable supports is the use of silica having a surface covering of a metal oxide, a possibility that has been under study in our laboratory for a decade. The rationale behind this concept is that by using a silica particle as base, the particle morphology and mesoporous structure of the bare silica will be maintained, insuring favorable pore sizes and surface areas, similar to those of silica. Moreover, the use of a metalized silica support should make the support less sensitive to dissolution at high $\mathrm{pH}$ due to the presence of more hydrolytically stable layers of metallic oxide.

This concept was first explored almost three decades ago, when silica with a layer of cromia $^{33}$ or of several other 
metals ${ }^{34}$ was evaluated for normal phase chromatography. However, the complicated preparation procedures meant that this approach never met with much success. More successfully, silica was first reacted with zirconyl chloride and then derivatized with an alkyl diol alkoxysilane. ${ }^{35}$ This stationary phase is still used for separation of biological macromolecules.

Silicas metalized with titanium or zirconium oxides have been explored as supports for preparation of stationary phases having polysiloxanes and other pre-formed polymers immobilized on the surface,,$^{36-48}$ using a strategy first explored in our laboratory using a bare silica surface. ${ }^{49,50}$ Although, the chemical properties of the metalized supports are different, they have proven to be excellent supports for immobilization of a polysiloxane layer over their surfaces. These metalized supports have also proven to be very useful to prepare chemically bonded $\mathrm{C}_{18}$ phases. ${ }^{51-56}$ Minor modifications of the usual organofunctionalization reactions have permitted obtaining $\mathrm{C}_{18}$-phases based on both titanized ${ }^{51-55}$ and zirconized silica. ${ }^{56}$

As already indicated, the search for stationary phases with better thermal and $\mathrm{pH}$ stability is a dominating factor in development of new HPLC procedures. The presence of free silanols on silica provides an opening for a base to attack and initiate dissolution of the support and this process is accelerated at higher temperatures, even at neutral $\mathrm{pH} .{ }^{57,58}$ Today, all manufacturers of stationary phases report "improved stability" for their new, sol-gel-based phases, but often the tests are not sufficiently rigorous. In addition, there is no accepted "standard test" so that comparisons are difficult to achieve. For high $\mathrm{pH}$ solutions, several organic bases have been used, including pyrrolidine, ${ }^{59}$ trimethylamine, ${ }^{60} 1$-methylpiperidine ${ }^{60}$ and glycine, ${ }^{58}$ although these amines are known to be less aggressive to the support than phosphate or carbonate salts at the same temperature ${ }^{58}$ Another variable is the identity of the organic modifier. Dissolution occurs more rapidly in methanolic solutions than when the modifier is acetonitrile. ${ }^{60} \mathrm{~A}$ further point is that many manufacturers report only the retention factor, a parameter that shows little change over longer times than either column efficiency or tailing factor. Silica dissolution and consequent formation of column voids are characterized by abrupt decreases in efficiency and similar increases in peak asymmetry, while retention factors remain unchanged, due to the continued presence of retentive organic moieties on the stationary phase.

The present paper relates recent studies of the stabilities of both immobilized polymer and organofunctionalized metalized silica phases, comparing them to commercial stationary phases based on high quality chromatographic silicas.

\section{Experimental}

\section{Preparation of the metalized silicas}

The zirconized and titanized silica supports were prepared by two distinct procedures. First, $5 \mu \mathrm{m}$ Kromasil silica (Akzo Nobel), activated at $110^{\circ} \mathrm{C}$ under vacuum for $8-12 \mathrm{~h}$, was immersed in dry (molecular sieves) toluene to which zirconium tetrabutoxide ${ }^{56}$ or titanium tetraisopropoxide ${ }^{52}$ and $150 \mu \mathrm{L}$ of water were added. The mixture was refluxed in a nitrogen atmosphere for $24 \mathrm{~h}$ and then cooled. The solution was filtered and the solid was washed successively with toluene, isopropanol, methanol and finally water, to promote hydrolysis of the remaining alkoxide groups. When a second layer was required, the procedure was repeated. In the second procedure, the metalized silicas were prepared by addition of zirconium tetrabutoxide ${ }^{37,61}$ or titanium tetraisopropoxide ${ }^{36,62}$ to silica suspensions in a test tube. The tube was then heated at $40{ }^{\circ} \mathrm{C}$ for a specified time, cooled, centrifuged and the resulting solid was thoroughly washed with toluene before hydrolyzing the remaining alkoxide groups with $10^{-3} \mathrm{~mol} \mathrm{~L}^{-1}$ $\mathrm{HNO}_{3}$. In most cases, this procedure was repeated to provide a double layer of metal oxide on the support surface.

In both cases, after drying under reduced pressure, the concentrations of metal present on the surface of the silica were determined by X-ray fluorescence (XRF) spectroscopy (Shimadzu EDX 700 spectrometer), using an analytical curve prepared from mixtures of silica and the appropriate metal oxide. Nuclear magnetic resonance (NMR) spectroscopy (Varian Inova 500) applying crosspolarization with magic angle spinning for ${ }^{29} \mathrm{Si}$, Fourier transformation infrared spectroscopy (FTIR) (PerkinElmer model 1600 or Bomen MB) in the interval between 4000 and $350 \mathrm{~cm}^{-1}$ as $\mathrm{KBr}$ pellets and specific surface area determinations (Micromeritics ASAP 2010) were also carried out on these metalized silicas.

Preparation of bonded $C_{18}$ phases by organofunctionalization

Appropriate quantities of the different metalized silicas, previously dried at $140^{\circ} \mathrm{C}$ for at least $12 \mathrm{~h}$, were suspended in toluene to which the octadecyltrimethoxysilane (or another trimethoxyalkylsilane) and an equimolar quantity of triethylamine were added. This mixture was refluxed for $48 \mathrm{~h}$ under nitrogen and, after cooling, the solid was filtered, washed with toluene, isopropanol, methanol and deionized water and then dried under vacuum at $60^{\circ} \mathrm{C}$ for $8 \mathrm{~h}$, prior to endcapping by refluxing with a large excess of TMCS and HMDS in toluene for $48 \mathrm{~h}$, followed by a similar work-up procedure. 
The new stationary phases were characterized by ${ }^{13} \mathrm{C}$ and ${ }^{29} \mathrm{Si}$ NMR, FTIR and elemental analysis (Perkin-Elmer model 2400 Analyzer). Chromatographic testing was carried out using $60 \mathrm{~mm} \times 3.9 \mathrm{~mm}$ (i.d.) $\mathrm{mm}$ stainless steel columns downward packed with a Haskell packing pump using 10\% $(\mathrm{m} / \mathrm{v})$ suspensions in chloroform or a mixture of isopropanol/ tetrahydrofuran $(1: 9, \mathrm{v} / \mathrm{v})$ at $34.5 \mathrm{MPa}$, with methanol as propulsion solvent. The chromatographic tests were carried out using a Shimadzu HPLC system with data acquired and processed using ChromPerfect software. The optimized flow rates were determined from van Deemter plots while the separation characteristics were evaluated using test mixtures suggested by Tanaka ${ }^{63}$ Engelhardt ${ }^{64}$ and Kele and Guiochon. ${ }^{65,66}$ When appropriate, the separation of selected pharmaceuticals or pesticides mixtures were also evaluated.

\section{Preparation of immobilized poly(methyltetradecylsiloxane) phases}

Appropriate quantities of dried $\left(140{ }^{\circ} \mathrm{C} / 12 \mathrm{~h}\right)$ metalized silica were added to $10 \%(\mathrm{v} / \mathrm{v})$ solutions of poly(methyltetradecylsiloxane) (PMTDS) dissolved in hexane. The mixtures were sonicated for $10 \mathrm{~min}$ and stirred for $3 \mathrm{~h}$ at room temperature, then were placed in a fume hood to allow slow evaporation of the solvent at room temperature (approximately one week). The sorbed stationary phase was placed in a stainless steel tube $(150 \mathrm{~mm} \times 10 \mathrm{~mm}$ (i.d.)) fitted with frits and connectors and placed in a tubular furnace to induce thermal immobilization by heating at $110^{\circ} \mathrm{C}$ for $12 \mathrm{~h}$ under a slow nitrogen flow. After immobilization, excess PMTDS was removed by connecting the stainless steel tube to a pump (Waters 510) and passing hexane at $50{ }^{\circ} \mathrm{C}$ for $4 \mathrm{~h}$.

One portion of PMTDS thermally immobilized onto zirconized silica was subjected to an endcapping reaction with excess TMCS + HMDS in refluxing toluene for $48 \mathrm{~h}$, followed by filtering, washing with toluene, isopropanol, methanol and methanol:water $(1: 1, \mathrm{v} / \mathrm{v})$ before drying under vacuum at $60{ }^{\circ} \mathrm{C}$ for $5 \mathrm{~h}$ prior to column packing.

Physical characterizations, column packing and chromatographic testing were carried using the procedures already described for the organofunctionalized phases.

\section{Stability testing of the phases}

The organofunctionalized and immobilized stationary phases, as well as several commercial stationary phases, packed into $60 \mathrm{~mm} \times 3.9 \mathrm{~mm}$ columns as already described, were subjected to stability testing. Briefly, the columns were placed in a chromatography oven at $50{ }^{\circ} \mathrm{C}$ and mobile phases of methanol:aqueous base were passed through at
$0.6 \mathrm{~mL} \mathrm{~min}{ }^{-1}$. Periodically, a test mixture containing uracil, $\mathrm{N}, \mathrm{N}$-dimethylaniline, naphthalene and acenaphthene was injected, utilizing the same mobile phase. The injections were made using a Shimadzu model SIL-10AD automatic injector programmed by a SCL-10C controller and the data were acquired and treated by the Shimadzu CLASS VP software. Two different basic solutions were used: $0.05 \mathrm{~mol} \mathrm{~L}^{-1} \mathrm{~K}_{2} \mathrm{HPO}_{4}$ and $0.05 \mathrm{~mol} \mathrm{~L}^{-1} \mathrm{~K}_{2} \mathrm{CO}_{3} / \mathrm{KHCO}_{3}$. Both these solutions had their $\mathrm{pH}$ adjusted to 10 with $\mathrm{KOH}$ using a calibrated $\mathrm{pH}$ meter (Digimed model 21) before mixing with methanol. The conditions used in this test accelerate stationary phase deterioration, making it possible to obtain faster evaluations using considerably less mobile phase and instrument time. ${ }^{67}$

\section{Results and Discussion}

\section{Stationary phases prepared by organofunctionalization of metalized silicas}

Titanized silicas having one or two separate layers of titania that were functionalized with trimethoxyoctadecylsilane and then endcapped ( $\mathrm{SiTiC}_{18}-\mathrm{H}_{2} \mathrm{O}$ and $\mathrm{Si}_{2} \mathrm{TiC}_{18}$, respectively) show $\mathrm{C}_{18}$ coverages similar to commercial $\mathrm{C}_{18}$ phases but reveal an increased acidity of the remaining hydroxyl groups. ${ }^{51,52,54,55}$ Without traces of water, $\mathrm{C}_{18}$ coverage is lower $\left(\mathrm{SiTiC}_{18}\right)$. The presence of the titania layer increased column lifetime by a factor of 1.25 , compared with a $\mathrm{C}_{18}$ prepared by an identical procedure using bare silica $\left(\mathrm{SiC}_{18}\right)$. Preparing the titanized silica phase with a urea-trialkoxyoctadecylsilane $\left(\mathrm{SiTiC}_{18}\right.$-urea) minimized undesirable interactions of the residual hydroxyls while maintaining increased stability. ${ }^{53}$ The retention factors of weakly basic compounds were lower and nearly symmetrical peaks were obtained in buffered mobile phases.

Octadecyl silane phases were also prepared using zirconized silica. ${ }^{56}$ Similar to the titanized-silica phases, the zirconized-silica phases $\left(\mathrm{SiZrC}_{18}\right.$ and $\left.\mathrm{SiZrC}_{18}-\mathrm{H}_{2} \mathrm{O}\right)$ exhibited higher retention with asymmetric peaks for basic compounds in unbuffered mobile phases but symmetrical peaks when either buffered mobile phases or mobile phases containing a small amount of an organic amine were used. These phases showed better thermal and $\mathrm{pH}$ stability than a similarly prepared silica$\mathrm{C}_{18}$ phase or any of the titanized silica phases.

To evaluate whether the insertion of a polar group into the long alkyl group would modify the apparent higher activity of the zirconized phase, a stationary phase based on zirconized silica having a carbamate group inserted into the chain was prepared by reacting a silica-zirconia support having $9 \%$ zirconia with 3(octadecylcarbamate) propyltriethoxysilane before endcapping $\left(\mathrm{SiZrC}_{18}\right.$-carb). Physical characterization of this new stationary phase by 
infrared and nuclear magnetic resonance spectroscopies confirmed the presence of carbamate containing $\mathrm{C}_{18}$ chain on the zirconized silica.

In contrast to the phases prepared on zirconized silica without the insertion of a polar group, this new stationary phase showed symmetrical peaks for aniline and dimethylaniline in an unbuffered mobile phase (Figure 1). This new phase also showed excellent stability, compared to that of a similarly prepared $\mathrm{C}_{18}$ phase on bare silica. Figure 2 shows the separation of five very basic drugs on the SiZrC18-carb phase using a pH 12 mobile phase of hexamethylenimine, an excellent volatile mobile phase additive for use with mass spectrometric detectors, at $40{ }^{\circ} \mathrm{C}$ after the first injection and after 100 consecutive injections. Neither peak shapes nor retention times were changed noticeably.

The effects of two different metallization layers were also evaluated by having a silica-based support prepared with a first layer of zirconia followed by a second layer of titania. This doubly metalized silica was then organofunctionalized with trimethoxyoctadecylsilane, followed by endcapping with a mixture of trimethylchlorosilane and hexamethyldisilazane $\left(\mathrm{SiZrTiC}_{18}\right)$ X-ray fluorescence indicated that zirconia represented $9.1 \%$ of the total mass and titania $8.7 \%$, suggesting the efficacy of formation of the
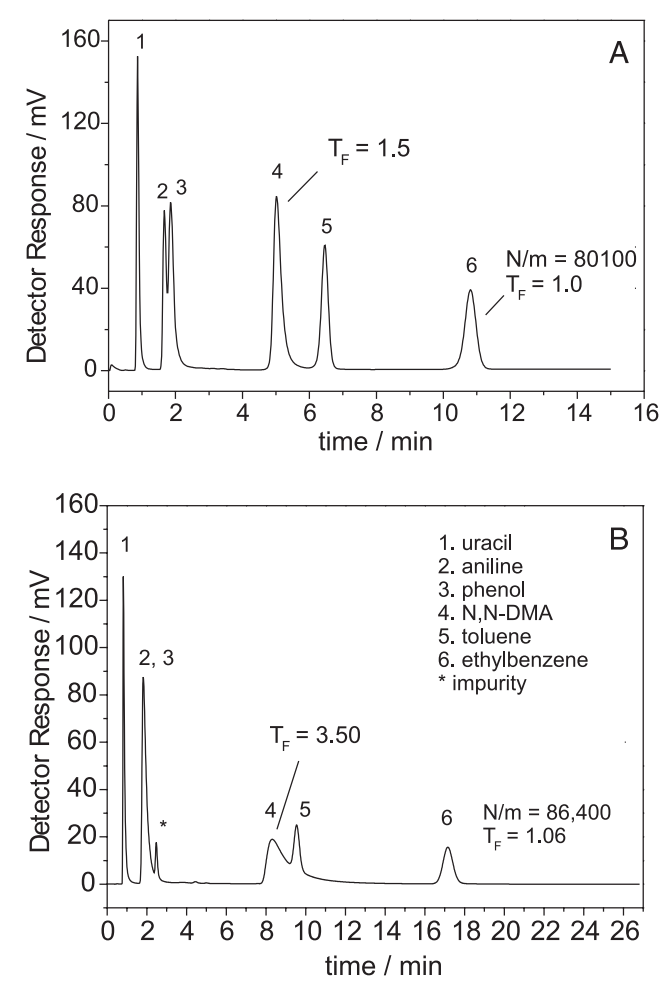

Figure 1. Chromatograms obtained on $60 \mathrm{~mm} \times 3.9 \mathrm{~mm}$ columns containing (A) $\mathrm{SiZrC}_{18}$-carb phase or (B) $\mathrm{SiZrC}_{18}$ phase. Chromatographic conditions: $\mathrm{MeOH}: \mathrm{H}_{2} \mathrm{O}(55: 45, \mathrm{v} / \mathrm{v})$; flow rate: $0.6 \mathrm{~mL} \mathrm{~min}^{-1}$; injection volume: $5 \mu \mathrm{L}$; detection: $\mathrm{UV}$ at $254 \mathrm{~nm}$. Peak identifications: (1) uracil, (2) aniline, (3) phenol, (4) N,N-dimethylaniline, (5) toluene, (6) ethylbenzene.
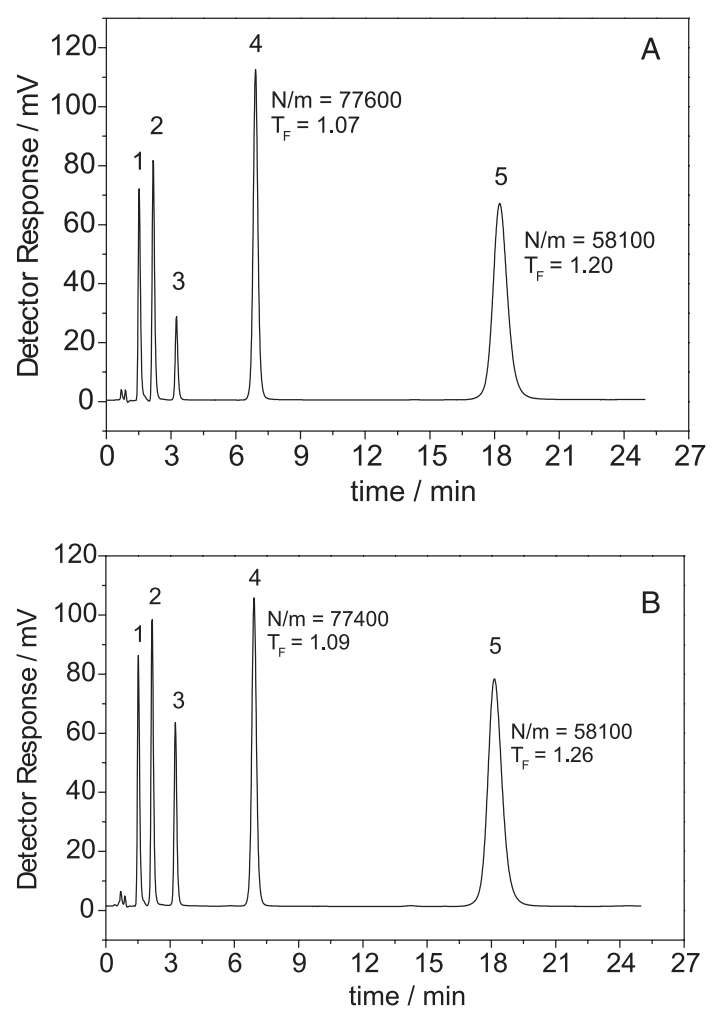

Figure 2. (A) Separation of (1) codeine, (2) prilocaine, (3) N, N-dimethylaniline, (4) naphthalene and (5) and amitriptyline on a $60 \mathrm{~mm} \times 3.9 \mathrm{~mm}$ $\mathrm{SiZrC}_{18}$-carb column at $0.6 \mathrm{~mL} \mathrm{~min}^{-1}$, using $\mathrm{MeOH}: 0.050 \mathrm{~mol} \mathrm{~L}^{-1}$ hexamethylenimine (HMI) buffer $(60: 40, \mathrm{v} / \mathrm{v})$ at $40{ }^{\circ} \mathrm{C}$. (B) Same separation after 100 consecutive injections.

Si-Zr-Ti linkages. After organofunctionalization elemental analysis and infrared and nuclear magnetic resonance spectroscopies all indicated the success of preparation of the new stationary phase.

Chromatographic evaluations using several test mixtures were carried out. The results from the Engelhardt test $^{64}$ are shown in Figure 3 and the parameters obtained from the Tanaka test ${ }^{63}$ are listed in Table 1, together with the results obtained for other $\mathrm{C}_{18}$ metalized phases. Stability evaluations indicate that the stability of the $\mathrm{SiZrTiC}_{18}$ phase is intermediate between stationary phases prepared from titanized silica and from zirconized silica.

\section{Stationary phases prepared by immobilization of} polysiloxanes onto metalized silicas

Silicas with layers of either titanium oxide or zirconium oxide have been used as supports for thermal or gamma irradiation immobilization of several polysiloxanes, including poly(methyloctylsiloxane), ${ }^{36-42}$ and poly(met hyltetradecylsiloxane) ${ }^{43-47}$ These immobilized polymer phases have shown good stabilities compared to commercial reversed phases having similar long-chain 
Table 1. Physico-chemical properties (metal oxide and $\mathrm{C}_{18}$ coverages) for the stationary phases and the parameters calculated from the chromatographic characterization by the Tanaka test mixtures

\begin{tabular}{|c|c|c|c|c|c|c|c|c|c|}
\hline & $\mathrm{MO}_{2} /\left(\mu \mathrm{mol} \mathrm{m}{ }^{-2}\right)$ & $\mathrm{C}_{18} /\left(\mu \mathrm{mol} \mathrm{m}{ }^{-2}\right)$ & $\mathrm{N} / \mathrm{m}$ values $\mathrm{a}, \mathrm{b}$ & $\alpha_{\mathrm{CH} 2}{ }^{\mathrm{b}}$ & $\alpha_{\mathrm{T} / \mathrm{O}}{ }^{\mathrm{b}}$ & $\alpha_{C / P}{ }^{c}$ & $\alpha_{\mathrm{B} / \mathrm{P}, \mathrm{pH} 7 .{ }^{\mathrm{d}}}$ & $\alpha_{\mathrm{B} / \mathrm{P}, \mathrm{pH} 2.7^{\mathrm{e}}}$ & Ref. \\
\hline SiZrTiC $_{18}$ & $9.6 \pm 0.3$ & $3.9 \pm 0.1$ & 78000 & 1.2 & 1.2 & 0.47 & - & 3.02 & this work \\
\hline $\mathrm{SiZrC}_{18}$ & $3.6 \pm 0.2$ & $3.7 \pm 0.2$ & 77000 & 1.2 & 1.1 & 0.38 & - & 7.8 & 56 \\
\hline $\mathrm{SiTiC}_{18}-\mathrm{H}_{2} \mathrm{O}$ & $10.9 \pm 0.3$ & $3.9 \pm 0.1$ & 74400 & 1.2 & 1.3 & 0.42 & - & 3.0 & 55 \\
\hline $\mathrm{Si}_{2} \mathrm{TiC}_{18}$ & $9.7 \pm 0.3$ & $3.5 \pm 0.1$ & 73700 & 1.3 & 1.1 & 0.55 & - & 2.5 & 54 \\
\hline $\mathrm{SiTiC}_{18}$ & $5.2 \pm 0.1$ & $3.5 \pm 0.1$ & 78200 & 1.2 & 1.2 & 0.56 & - & 7.8 & 52 \\
\hline $\mathrm{SiC}_{18}$ & 0 & $3.5 \pm 0.1$ & 70400 & 1.2 & 1.0 & 0.43 & 1.3 & 0.08 & 52 \\
\hline
\end{tabular}

Conditions: $60 \mathrm{~mm} \times 3.9 \mathrm{~mm}$ column; flow rate: $0.6 \mathrm{~mL} \mathrm{~min}^{-1}$; temperature: $40{ }^{\circ} \mathrm{C}$, detection: $\mathrm{UV}$ at $254 \mathrm{~nm}$; injection volume: $5 \mu \mathrm{L}$. ${ }^{\mathrm{C} C a l c u l a t e d ~ f o r ~}$ butylbenzene; ' ${ }^{\mathrm{b}}$ methanol-water (80:20 v/v); ${ }^{\mathrm{c}}$ methanol-water (30:70 v/v); ${ }^{\mathrm{d}}$ methanol-20 mmol L ${ }^{-1} \mathrm{H}_{3} \mathrm{PO}_{4} / \mathrm{KH}_{2} \mathrm{PO}_{4}$ buffer $(30: 70 \mathrm{v} / \mathrm{v})$ at $\mathrm{pH} 7.60$; ${ }^{\mathrm{e}} \mathrm{methanol}-$ $20 \mathrm{mmol} \mathrm{L}-1 \mathrm{KH}_{2} \mathrm{PO}_{4} / \mathrm{K}_{2} \mathrm{HPO}_{4}$ buffer $(30: 70 \mathrm{v} / \mathrm{v})$ at $\mathrm{pH} 2.70 . \mathrm{MO}_{2}$ indicates the quantity of the appropriate metal (as its oxide) determined by XRF.
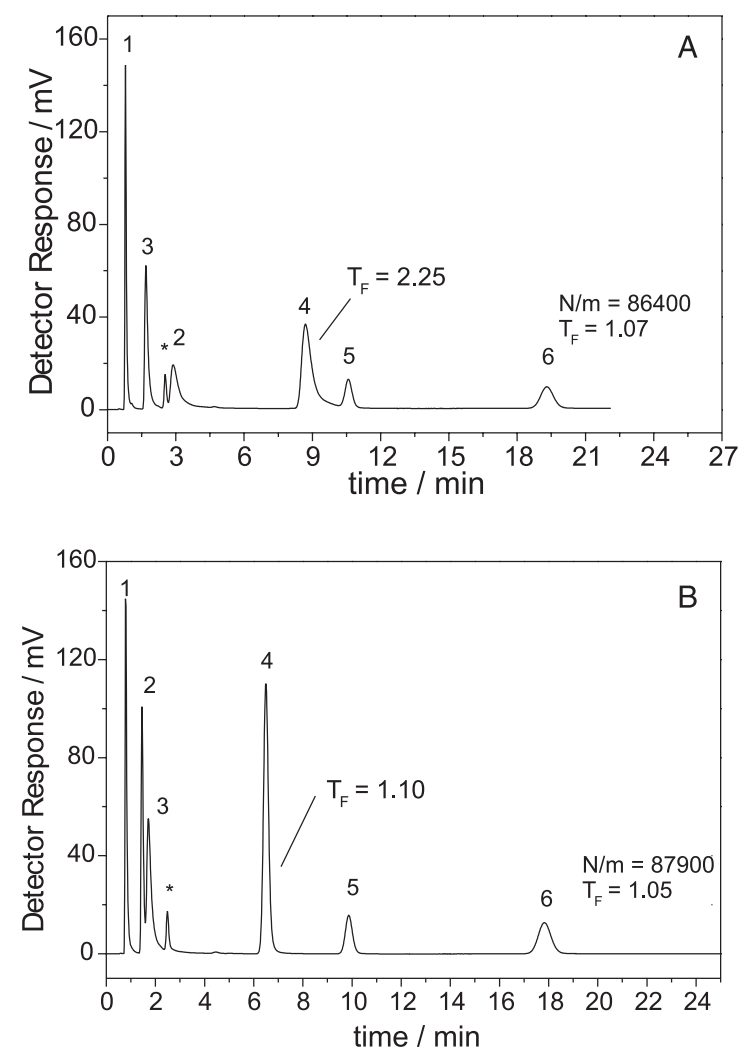

Figure 3. Chromatograms of some components of the Engelhardt test mixture on the $60 \mathrm{~mm} \times 3.9 \mathrm{~mm} \mathrm{SiZrTiC} \mathrm{column} \mathrm{at} 0.6 \mathrm{~mL} \mathrm{~min}^{-1}$, using (A) $\mathrm{MeOH}: \mathrm{H}_{2} \mathrm{O}(55: 45, \mathrm{v} / \mathrm{v})$ and (B) $\mathrm{MeOH}: 0.020 \mathrm{~mol} \mathrm{~L}^{-1}$ phosphate buffer (55:45, v/v) at $\mathrm{pH} 7.0$. Peak identifications: (1) uracil, (2) aniline, (3) phenol, (4) N,N-dimethylaniline, (5) toluene, (6) ethylbenzene, $*$ refers to an impurity.

alkyl substituents. Similar to the results described above for the organofunctionalized phases, those based on zirconized silica ${ }^{43-45}$ show greater stability than those based on titanized silica. ${ }^{46,47}$ Stability in basic solutions is further enhanced if an endcapping reaction with a mixture of trimethylchlorosilane and hexamethyldisilazane is carried out. ${ }^{48}$ Figure 4 compares chromatograms of a mixture of test solutes on zirconized silica having a thermally immobilized poly(methyltetradecylsiloxane) coating with (SiZr(PMTDS) ec) and without (SiZr(PMTDS)) endcapping, showing that the endcapping reaction has reduced the acidity of residual hydroxyls, yielding symmetrical peaks. Figure 5 compares the efficiencies observed during the stability tests in a nominally $\mathrm{pH} 10$ solution of potassium carbonate at $50^{\circ} \mathrm{C}$ for both phases. Both zirconized silica phases have longer lifetimes when compared to a commercial $\mathrm{C}_{18}$ phase, while
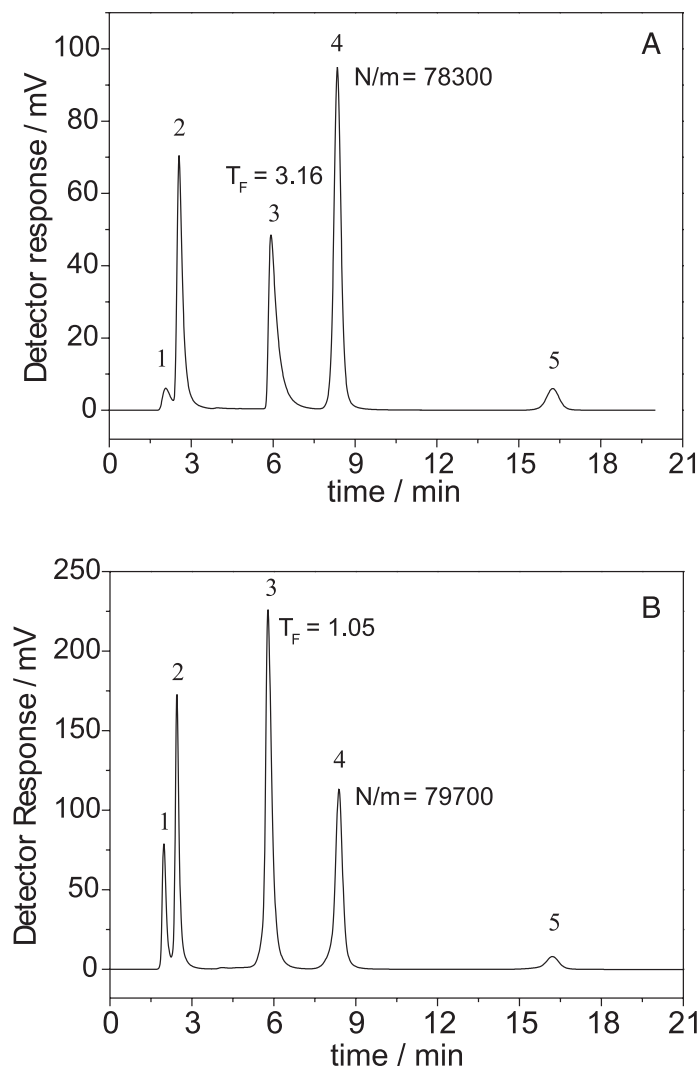

Figure 4. Separation of a test mixture on $60 \mathrm{~mm} \times 3.9 \mathrm{~mm}$ columns containing (A) non-endcapped and (B) endcapped SiZr(PMTDS). Mobile phase: $\mathrm{MeOH}: \mathrm{H}_{2} \mathrm{O}(70: 30, \mathrm{v} / \mathrm{v})$; flow rate: $0.3 \mathrm{~mL} \mathrm{~min}^{-1}$; injection volume: $5 \mu \mathrm{L}$; detection: $\mathrm{UV}$ at $254 \mathrm{~nm}$; temperature: $40^{\circ} \mathrm{C}$. Peak identifications: (1) uracil, (2) phenol, (3) N,N-dimethylaniline, (4) naphthalene and (5) acenaphthene. 
the endcapped phase is nearly three times more stable than the non-endcapped one. This shows the very significant effect of reducing even the small amount of residual silanols present after immobilization of the polysiloxane phase.

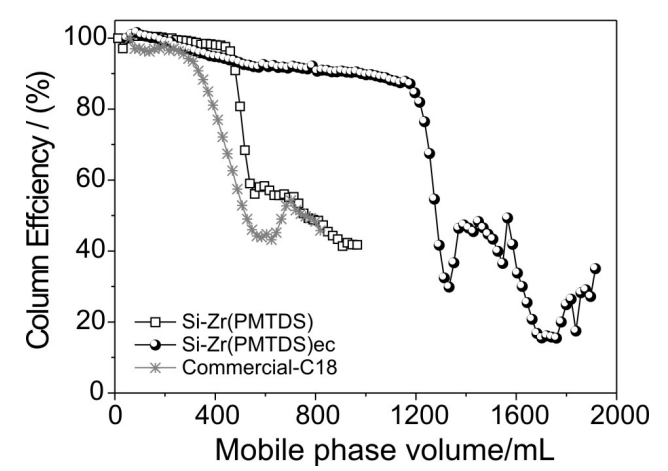

Figure 5. Variation of the column efficiencies of non-endcapped and endcapped SiZr(PMTDS) and of a commercial chemically-bonded $\mathrm{C}_{18}$ stationary phase. Mobile phase: $\mathrm{MeOH}: 0.050 \mathrm{~mol} \mathrm{~L}^{-1} \mathrm{~K}_{2} \mathrm{CO}_{3}$ at $\mathrm{pH} 10$; flow rate: $1.0 \mathrm{~mL} \mathrm{~min}{ }^{-1}$; temperature: $50{ }^{\circ} \mathrm{C}$; test probe: acenaphthene.

\section{Comparative stability tests of stationary phases prepared on metalized silica}

Stationary phase stability, based on resistance to dissolution of silica at $\mathrm{pH}$ greater than 8 , is essential for many analytical procedures. Most of column manufacturers use an "in house" test to affirm the stability of their products, as there is no standardized test. In order to be able to more rapidly evaluate the stability of the various metalized silica phases prepared by our laboratory and to make possible comparisons between these phases and several commercial phases, an accelerated stability test using nominally $\mathrm{pH} 10$ solutions of either carbonate or phosphate salts at $50{ }^{\circ} \mathrm{C}$ was proposed. ${ }^{67}$ These two mobile phases, differing in the inorganic salt present, show some interesting differences in their behavior. Figure 6 shows the different effects that these two inorganic salts, both prepared at $\mathrm{pH} 10$ with $0.050 \mathrm{~mol} \mathrm{~L}^{-1}$ aqueous salt concentrations, have on a commercial $\mathrm{C}_{18}$ phase at $50^{\circ} \mathrm{C}$. The collapse of the column bed occurs almost three times as fast using the carbonate buffer. The distinctly different behavior is explained by the effective $\mathrm{pH}$ of the nominally $\mathrm{pH} 10$ methanol:aqueous salt solutions: the effective $\mathrm{pH}$ of a methanol:aqueous carbonate solution after adding methanol to the $\mathrm{pH} 10$ aqueous solution is 11.4 while that of a similarly prepared methanol:phosphate solution is 10.6. ${ }^{68}$ However, both these solutions are much more effective at dissolving a silica support than any of the organic bases that have been evaluated.

As shown in Figure 6, the retention factor does not change significantly while the efficiency (plates per meter) and the tailing factor show abrupt changes at similar column volumes, confirming that retention factor is not a viable measure of stationary phase stability in basic solutions.

Tests with both inorganic salts, prepared in $\mathrm{pH} 10$ aqueous solutions and at $50{ }^{\circ} \mathrm{C}$, have been used to evaluate the stabilities of metalized silica phases prepared both by immobilization of polysiloxanes and by organofunctionalization in our laboratory. Comparisons of the stabilities of these phases, of phases made by organofunctionalization or immobilization on bare silica
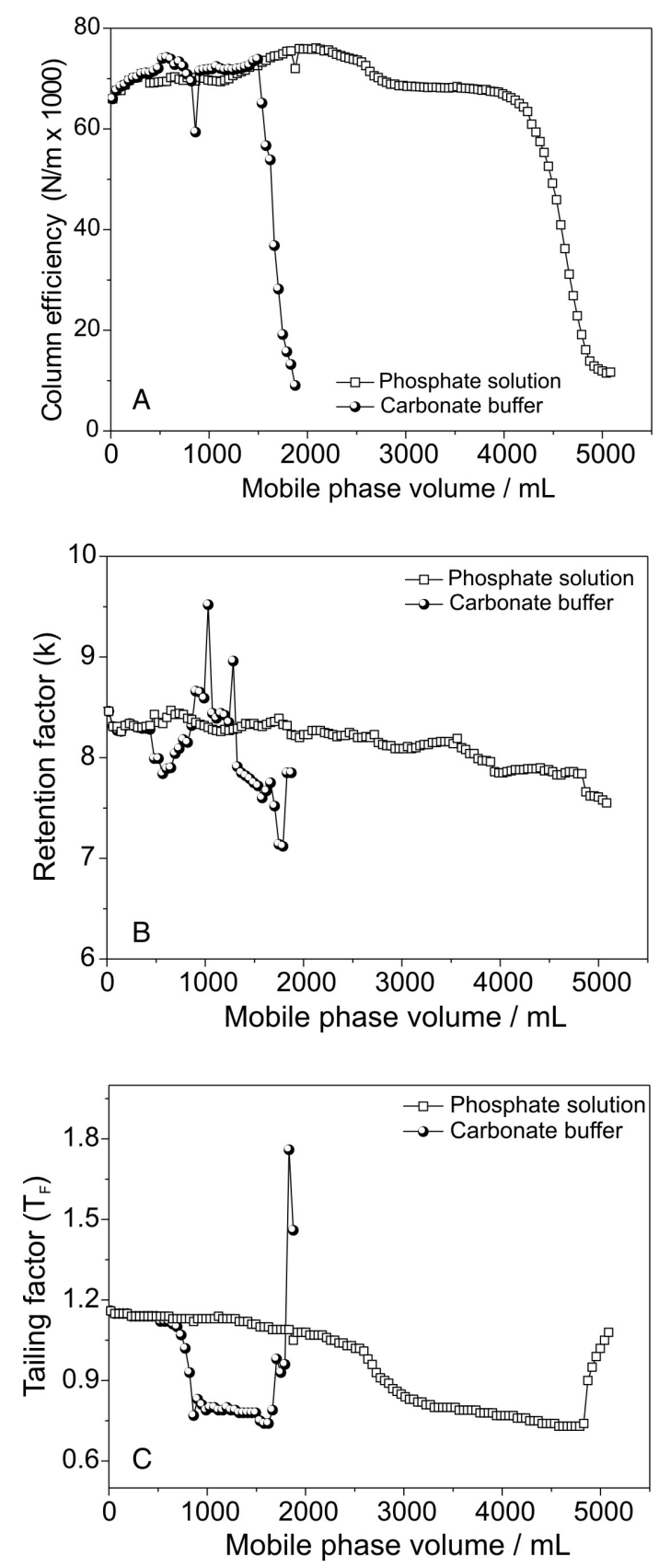

Figure 6. Column efficiency (A), retention factor (B) and tailing factor (C), calculated for acenaphthene, during stability tests on $60 \mathrm{~mm} \times 3.9 \mathrm{~mm}$ columns packed with a commercial $\mathrm{C}_{18}$ phase. Mobile phase: $(70: 30, \mathrm{v} / \mathrm{v})$ MeOH:0.050 mol L-1 $\mathrm{K}_{2} \mathrm{HPO}_{4}$ solution or $\mathrm{K}_{2} \mathrm{CO}_{3} / \mathrm{KHCO}_{3}$ buffer at pH 10.0; flow rate: $0.6 \mathrm{~mL} \mathrm{~min}^{-1}$; temperature: $50{ }^{\circ} \mathrm{C}$. 
and of several commercial phases, as revealed by the effect of the aggressive mobile phases on column efficiencies, are shown in Figures 7 and 8. These figures confirm that carbonate is more aggressive than phosphate under these conditions and that the phases based on zirconized silica are more stable than those based on titanized silica. They also show that both the organofunctionalized and immobilized phases have better stabilities than the commercial stationary phases evaluated, indicating the promise that this direction has in enhancing stationary phase stability and, thus, improving routine analytical determinations.
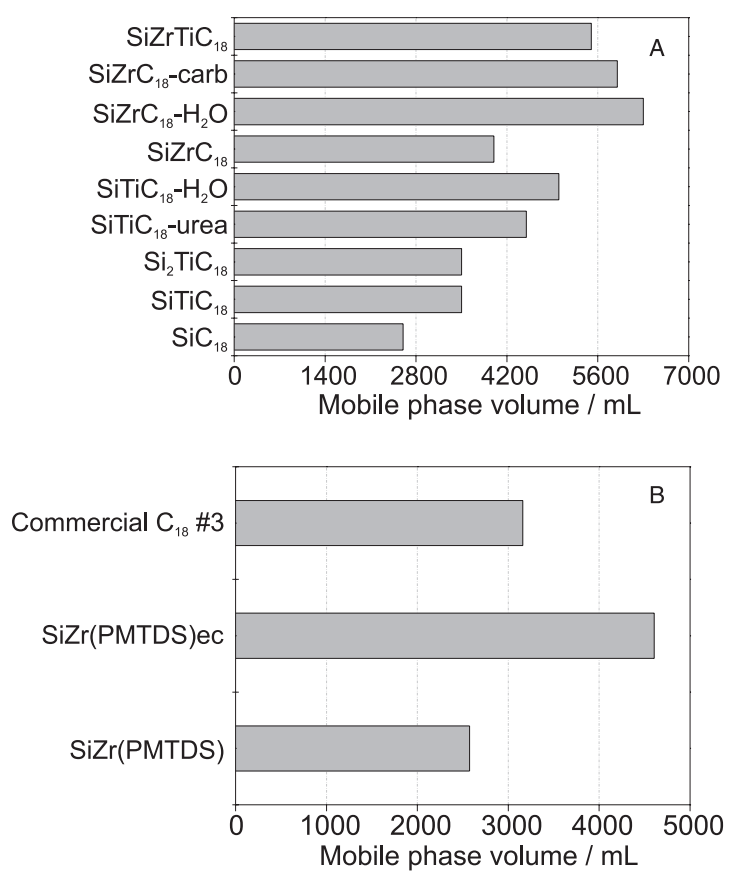

Figure 7. Hydrolytic stability of laboratory-made stationary phases and a commercial stationary phase. Mobile phase volume (calculated from mobile phase retention determined using uracil) that causes a 50\% decrease in the column efficiency measured with acenaphthene while passing MeOH:0.050 mol L-1 $\mathrm{K}_{2} \mathrm{HPO}_{4} / \mathrm{KH}_{2} \mathrm{PO}_{4}$ (nominally $\mathrm{pH} 10$ ) mobile phase at $50{ }^{\circ} \mathrm{C}$. (A) stationary phases prepared by organofunctionalization; (B) stationary phases prepared by immobilization of poly(methyltetrad ecylsiloxane).

\section{Conclusions}

The efforts of our laboratory toward developing more stable stationary phases for use in routine analysis that require basic solutions, such as the separations of many pharmaceuticals or pesticides has resulted in several promising stationary phases using metalized silicas as supports. At the present stage of development, zirconized-silica supports appear more promising than do those with a titania layer. For organofunctionalized stationary phases, those prepared with a polar group inserted into the long alkyl substituent show less

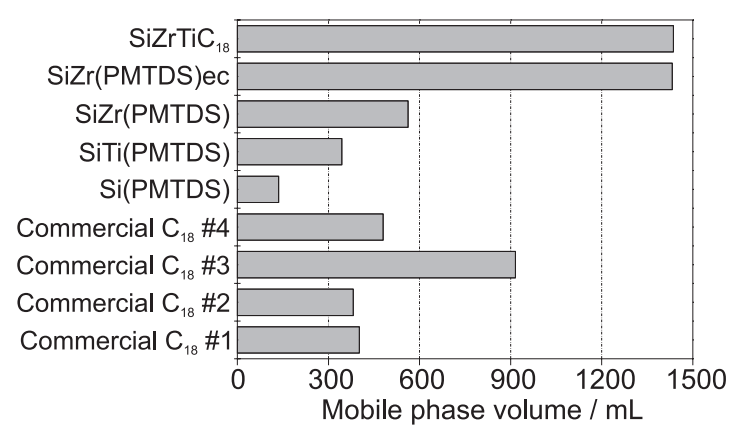

Figure 8. Hydrolytic stability of laboratory-made stationary phases and several different commercial stationary phases. Mobile phase volume (calculated from mobile phase retention determined using uracil) that causes a 50\% decrease in the column efficiency measured with acenaphthene while passing $\mathrm{MeOH}: 0.050 \mathrm{~mol} \mathrm{~L}^{-1} \mathrm{~K}_{2} \mathrm{CO}_{3} / \mathrm{KHCO}_{3}$ (nominally $\mathrm{pH} 10$ ) mobile phase at $50{ }^{\circ} \mathrm{C}$.

peak asymmetry with basic compounds than do the other organofunctionalized phases. The addition of an endcapping step after immobilization of a polysiloxane appears to significantly increase the stability while also reducing the peak asymmetries of basic compounds. At present new stationary phases presenting other functionalities for specific types of separations are under evaluation, with encouragingly positive results.

\section{References}

1. Kirkland, J. J.; J. Chromatogr. Sci. 1970, 10, 593.

2. Huber, J. F. K.; Kolder, F. F. M.; Miller, J. M.; Anal. Chem. 1972, 44, 105.

3. Halasz, I.; Sebestian, I.; Angew. Chem. Int. Ed. 1969, 8, 453.

4. Locke, D. C.; Schmermund, J. T.; Banner, B.; Anal. Chem. 1972, 44, 90 .

5. Brust, O. E.; Sebestian, I.; Halasz, I.; J. Chromatogr. 1973, 83, 15.

6. Kirkland, J. J.; DeStefano, J. J.; J. Chromatogr. Sci. 1970, 8, 309.

7. Kirkland, J. J.; J. Chromatogr. Sci. 1971, 9, 206.

8. Majors, R. E.; LC-GC North Am. 1994, 12, 508.

9. Kirkland, J. J.; J. Chromatogr. A 2004, 1060, 9.

10. Fairbank, R. W.; Wirth, M. J.; J. Chromatogr. A 1999, 830, 285.

11. Kirkland, J. J.; Glajch, J. L.; Farlee, R. D.; Anal. Chem. 1989, 61,2 .

12. Kirkland, J. J.; Henderson, J. W.; J. Chromatogr. Sci. 1994, 32, 473.

13. Kirkland, J. J.; Adams Jr., J. B.; van Straten, M. A.; Claessens, H. A.; Anal. Chem. 1998, 70, 4344.

14. Czajkowska, T.; Jaroniec, M.; J Chromatogr. A 1997, 762, 147.

15. Kirkland, J. J.; Henderson, J. W.; Martosella, J. D.; Bidlingmeyer, B. A.; Vasta-Russel, J.; Adams Jr., J. B.; LC-GC 1999, 17, 634.

16. O'Gara, J. E.; Alden, B. A.; Walter, T. H.; Petersen, J. S.; Niederlaender, C. L.; Neue, U. D.; Anal. Chem. 1995, 67, 3908.

17. Silva, C. R.; Jardim, I. C. S. F.; Airoldi, C.; J. Chromatogr. A 2001, 913, 65 . 
18. Silva, C. R.; Collins, C. H.; Jardim, I. C. S. F.; Airoldi, C.; J. Chromatogr. A 2004, 1030, 157.

19. Silva, R. B.; Silva, C. R.; Airoldi, C.; Collins, C. H.; Jardim, I. C. S. F.; Microchem. J. 2006, 82, 150.

20. Wirth, M. J.; Fatunmbi, H. O.; Anal. Chem. 1993, 65, 822.

21. Akapo, S. O.; Fatunmbi, H. O.; LC-GC 1999, 17, 334.

22. Neue, U. D.; Walter, T. H.; Alden, B. A.; Jiang, Z.; Fish, R. P.; Cook, J. J.; Glose, K. H.; Carmody, J. L.; Grassi, J. M.; Cheng, Y. F.; Lu, Z.; Crowley, R. J.; Am. Lab. 1999, 31, 36.

23. Cheng, Y.-F.; Walter, T. H.; Lu, Z.; Iraneta, P.; Alden, B. A.; Gendreau, C.; Neue, U. D.; Grassi, J. M.; Carmody, J. L.; O'Gara, J. E.; Fisk, R. P.; LC-GC 2000, 18, 1162.

24. Wyndhan, K. D.; O'Gara, J. E.; Walter, T. H.; Glose, K. H.; Lawrence, N. L.; Alden, B. A.; Izzo, G. S.; Hudalla, C. J.; Iraneta, P. C.; Anal. Chem. 2003, 75, 6781.

25. Majors, R. E.; LC-GC Current Issues in HPLC Technology May 1997, S8-S19.

26. Pereira, L.; Aspey, S.; Ritchie, H.; J. Sep. Sci. 2007, 30, 1115.

27. Engelhardt, H.; Low, H.; Eberhardt, W.; Mausse, M.; Chromatographia 1989, 27, 535.

28. Hanson, M.; Kurganov, A.; Unger, K. K.; Davankov, V. A.; J. Chromatogr. A 1993, 656, 369.

29. Nawrocki, J.; Dunlap, C.; McCormick, A.; Carr, P. W.; J. Chromatogr. A 2004, 1028, 1.

30. Nawrocki, J.; Dunlap, C.; Li, J.; Zhao, J.; McNeff, C. V.; McCormick, A.; Carr, P. W.; J. Chromatogr. A 2004, 1028, 31.

31. Teutenberg, T.; Tuerk, J.; Holzhauser, M.; Giegold, S.; J. Sep. Sci. 2007, 30, 1101.

32. Smith, R. M.; J. Chromatogr. A 2008, 1184, 441.

33. Aue, W. A.; Wickramanayake, P. P.; J. Chromatogr. 1980, 197, 21.

34. Aigner-Held, R.; Aue, W. A.; Pickett, E. E.; J. Chromatogr. 1980, 189, 139.

35. Stout, R. W.; DeStefano, J. J.; J. Chromatogr. 1985, 326, 63.

36. Silva, R. B.; Collins, C. H.; J. Chromatogr. A 1999, 845, 417.

37. Melo, L. F. C.; Jardim, I. C. S. F.; J. Chromatogr. A 1999, 845, 423.

38. Melo, L. F. C.; Collins, C. H.; Collins, K. E.; Jardim, I. C. S. F.; J. Chromatogr. A 2000, 869, 129.

39. Silva, R. B.; Collins, K. E.; Collins, C. H.; J. Chromatogr. A 2000, 869, 137.

40. Silva, R. B.; Gushikem, Y.; Collins, C. H.; J. Sep. Sci. 2000, 24 , 129.

41. Melo, L. F. C.; Collins, K. E.; Collins, C. H.; Jardim, I. C. S. F.; J. Chromatogr. A 2001, 869, 49.

42. Fonseca, D. A.; Collins, K. E.; Collins, C. H.; J. Chromatogr. A 2004, 1030, 209.

43. Faria, A. M.; Collins, K. E.; Collins, C. H.; J. Chromatogr. A 2006, 1122, 144.

44. Faria, A. M.; Jardim, I. C. S. F.; Collins, K. E.; Collins, C. H.; J. Sep. Sci. 2006, 29, 782.
45. Faria, A. M.; Collins, K. E.; Collins, C. H.; J. Chromatogr. A 2007, 1156, 51.

46. Faria, A. M.; Tonhi, E.; Collins, K. E.; Collins, C. H.; J. Sep. Sci. 2007, 30, 1844.

47. Faria, A. M.; Collins, K. E.; Collins, C. H.; Chromatographia 2008, 67, 357.

48. Faria, A. M.; Silva, C. R.; Collins, C. H.; Jardim, I. C. S. F.; J. Sep. Sci. 2008, 31, 953.

49. Anazawa, T. A.; Jardim, I. C. S. F.; J. Liq. Chromatogr. 1994, $17,1265$.

50. Jardim, I. C. S. F.; Collins, K. E.; Collins, C. H.; Microchem. J. 2004, 77, 191.

51. Silva, C. R.; Airoldi, C.; Collins, K. E.; Collins, C. H.; LCGC North Am. 2004, 22, 632.

52. Silva, C. R.; Airoldi, C.; Collins, K. E.; Collins, C. H.; J. Chromatogr. A 2005, 1073, 155.

53. Silva, C. R.; Airoldi, C.; Collins, K. E.; Collins, C. H.; J. Chromatogr. A 2005, 1087, 29.

54. Silva, C. R.; Airoldi, C.; Collins, K. E.; Collins, C. H.; J. Chromatogr. A 2005, 1114, 45.

55. Silva, C. R.; Collins, C. H.; Collins, K. E.; Airoldi, C.; J. Sep. Sci. 2006, 29, 790.

56. Silva, C. R.; Airoldi, C.; Collins, K. E.; Collins, C. H.; J. Chromatogr A 2008, 1191, 90.

57. Claessens, H. A.; van Straten, M. A.; Kirkland, J. J.; J. Chromatogr. A 1996, 728, 259.

58. Claessens, H. A.; van Straten, M. A.; J. Chromatogr. A 2004, 1060, 23.

59. Kirkland, J. J.; Henderson, J. W.; DeStefano, J. J.; van Straten, M. A.; Claessens, H. A.; J. Chromatogr. A 1997, 762, 97.

60. Kirkland, J. J.; van Straten, M. A.; Claessens, H. A.; J. Chromatogr. A 1998, 797, 111.

61. Faria, A. M.; Magalhães, D. R.; Collins, K. E.; Collins, C. H.; Anal. Chim. Acta 2005, 550, 137.

62. Faria, A. M.; Magalhães, D. R.; Collins, C. H.; Revista Materia 2004, 9, 344 <http://www.materia.coppe.ufrj.br/sarra/artigos/ artigo10614/10614.pdf>.

63. Kimata, K.; Iwaguchi, K.; Onishi, S.; Jinni, K.; Eksteen, R.; Hosoya, M.; Araki, M.; Tanaka, N.; J. Chromatogr. Sci. 1989, 27,721 .

64. Engelhardt, H.; Jungheim, M.; Chromatographia 1990, $29,59$.

65. Kele, M.; Guiochon, G., J. Chromatogr. A 1999, 855, 423.

66. Kele, M.; Guiochon, G., J. Chromatogr. A 2000, 869, 181.

67. Fonseca, D. A.; Gutierrez, H. R.; Collins, K. E.; Collins, C. H.; J. Chromatogr. A 2004, 1030, 149.

68. Tindall, G. W.; Perry, R. L.; J. Chromatogr. A 2003, 988, 309.

Received: December 10, 2008 Web Release Date: March 13, 2009

FAPESP helped in meeting the publication costs of this article. 